\title{
New and interesting Chrysobalanaceae from Amazonia
}

\begin{abstract}
In this paper the most interesting and recent collections made by the author in the Amazonian Brazil and by other collectors are discussed here in this addition to his monograph of the Neotropical members of the Chrysobalanaceae. Three new species are also descrideb.
\end{abstract}

\section{INTRODUCTION}

Since the preparation of my monograph of the Neotropical members of the Chrysobala. naceae (Prance, 1972), I have made 136 further collections during a year of fieldwork in Amazonian Brazil in collaboration with the Instituto Nacional de Pesquisas da Amazônia. The most interesting of these recent collections as well as a few made by other collectors are discussed here in this first addition to the monograph, and 3 new species are described. Some of the collections cited are very large range extensions, particularly of species previously known only from around Manaus (Fig. 1). This is indicative of the need for further collections away from the population centers to fill in the many distribution gaps in our knowledge of the Amazon flora.

\section{Licania Aubl.}

Licania jimenezii Prance, sp. nov.

(Fig. 2)

Arbor $26 \mathrm{~m}$ alta, ramulis juvenilibus tomentellis mox glabris. Stipulae caducae (haud visae). Folia alternata, petiolata, petiolo $15-20$ $\mathrm{mm}$ "longo, leviter canaliculato, breviter tomentello, versus basim cum glandulis duobus vel pluribus munito; laminae oblongo-ellipticae, $14-19 \mathrm{~cm}$ longae, $6-7.5 \mathrm{~cm}$ latae, apice in acuminem 10-18 mm longum contractae, basi subcuneatae, supra glabrae, subtus dense lanatae, profunde reticulatae; costa media supra impressa versus basim tomentella, subtus prominenti; costis secundariis 9-11 jugis supra planis subtus prominentibus. Flores circa $2.5 \mathrm{~mm}$ longi in paniculis terminalibus axillaribusque dispositi, rachi ramisque tomentellis. Bracteae bracteolaeque ovato-lanceolatae circa $0.6 \mathrm{~mm}$ longae persistentes, pubescentes. Receptaculum campanulatum, extus tomentellum, intus tomentosum; pedicello circa $0.4 \mathrm{~mm}$ longo. Calycis-lobi 5 , tomentosi. Petala nulla. Stamina 7 , unilateralia, inclusa, 3 grandes, 4 parviores steriles, filamentis glabris, liberis. Ovarium ad basim receptaculum insertum, lanato-pubescens. Stylus e basi ovarii ortus, ad apicem lanatus. Fructus mihi ignoti.

Type: H. Jiménez-Saa 1549, Suriname, Fallawatra, Nickerie District, mesophytic forest, flowering November 1971 (holotype, NY; isotype, LBB 14282).

\section{Local name: Rode Kwepi (Suriname)}

This species belongs to Licania subgenus Licania, section Licania. It is, however, most distinct not easily confused with any other species. The numerous axillary inflorescences, and the two types of stamens distinguish this species. The larger stamens are fertile, the smaller ones have well developed anthers but abortive pollen. L. jimenezii is probably closest to $L$. alba and $L$. robusta. It differs from $L$. alba in the much smaller bracteoles and flowers, the less conspicous leaf reticulations, the longer petioles, and the stamens etc., and from $L$. robusta in the smaller flowers, the pubescent inflorescence, the grandular petioles, the caducous stipules, the impressed midrib etc. 
Licania couepifolia Prance, FI. Neotropica 9: 134. 1972.

Oldenburger, Norde \& Schulz 1256, Suriname, Sipalwini area, $56^{\circ} 5^{\prime}-56^{\circ} 15^{\prime} \mathrm{W} ; 1^{\circ} 50^{\prime}-$ $2^{\circ} 5 \mathrm{~N}$, fruiting 1971, lowland tropical forest (NY, LBB).

This is the second collection of this most distinct species of Licania, which was first collected from Guyana in the Essequibo river basin. The Suriname material adds fruits for the first time. The young fruits are pyriform, $2.5 \mathrm{~cm}$ long, with a much wrinkled velutinous epicarp.

Licania kunthiana Hook. f. Mart. Fl. Bras. 14 (2) : 16. 1867.

Maas et al. 12658, Brazil, Acre, Serro de Moa, flowering April 29, 1971.
This first collection of $L$. kunthiana from Acre, considerably extends to the southwest the known range of the widespread species.

Licania wurdackii Prance, Fl. Neotropica 9: 63. 1972

Prance et al. 15426, Brazil. Amazonas, Rio Uneiuxi, $2 \mathrm{~km}$ above mouth, flowering 15 October 1971 .

This species was described from material collected in Venezuela and on the Rio Negro above Uaupés. Thus, the present collection cxtends the range considerably eastwards. The plant was a shrub of $3 \mathrm{~m}$ with numerous separate trunks, growing amongst rocks, and its habit is quite different from $L$. apetala to which it is most closely related.

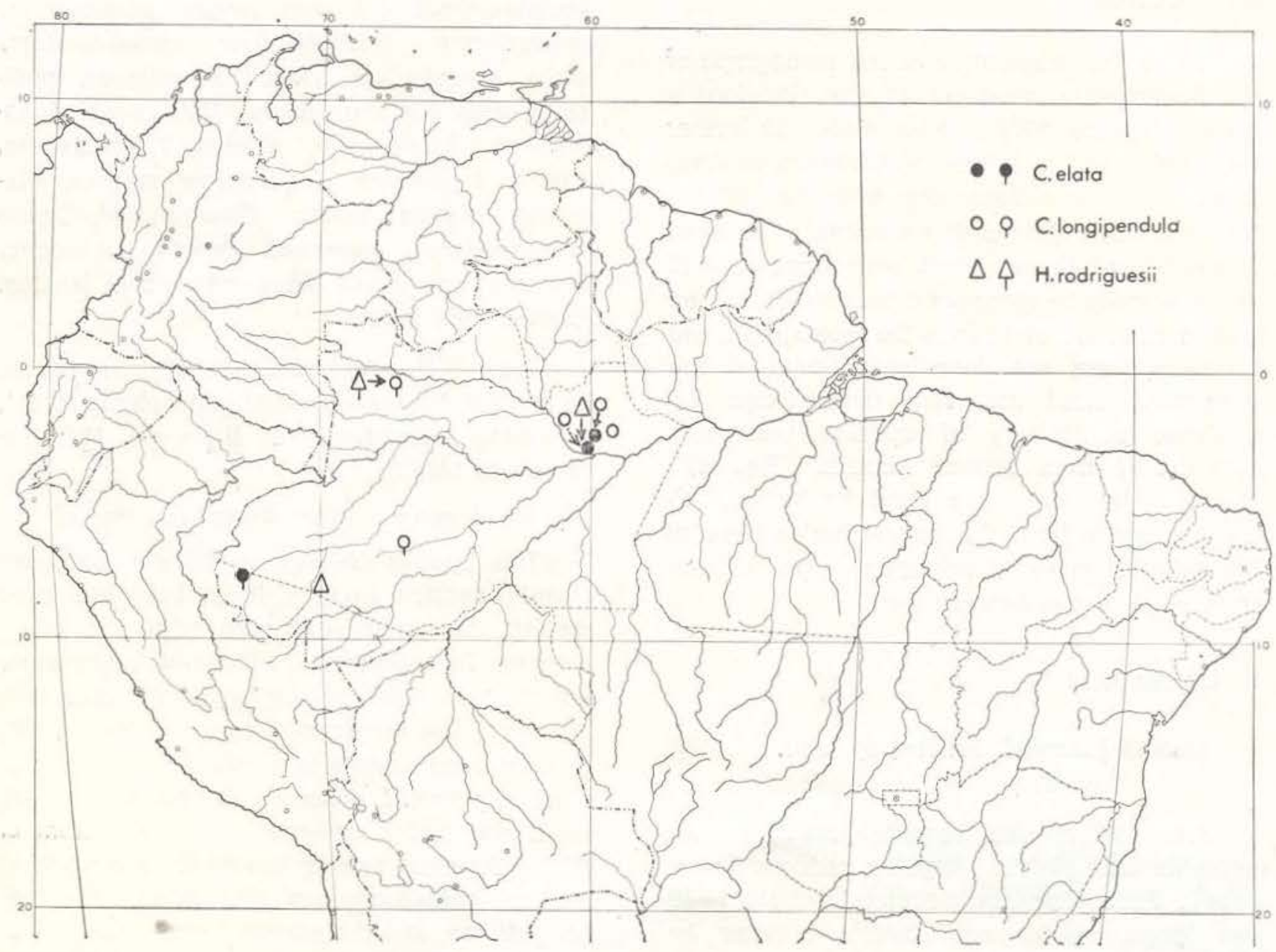

F:G. 1 - Distribution map showing some range extensions from 1971 fieldwork, $\bullet, \mathbf{i}=$ Couepia elata Ducke; $\circ, \varphi=$ Couepia Iongipendula Pilg.; $\hat{\Lambda}, \hat{\imath}=$ Hirtella rodriguesii Prance. The symbols with a line beneath represent the range extensions by 1971 collections. 


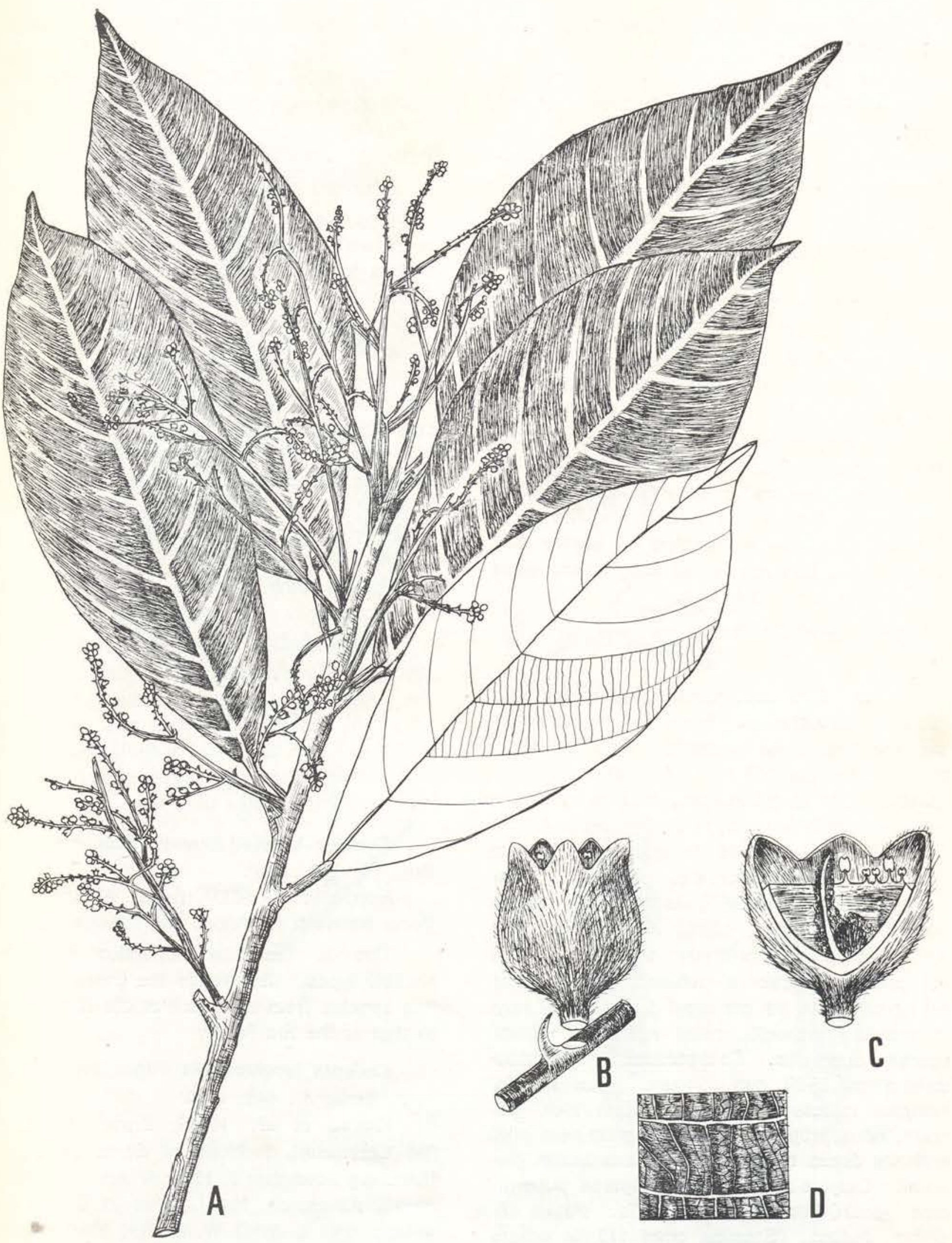

FIG. 2 - Licania jimenezii (H. Jiménez-Saa 1549). A, habit, x $0.5 ;$ B, flower, x 13; C. flower section, x 13; D, leaf undersurface, $\times 2$. 
Licania urceolaris Hook. f., Mart. Fl. Bras 14 (2) : 15. 1867.

Prance et al. 11939, Brazil, Acre, Cruzeiro do Sul, Estrada Alemanha, fruiting April 15. 1971.

This is the first collection of this species from Acre.

\section{Couepia Aubl.}

Couepia elata Ducke, Archiv. Inst. Biol. Veg. Rio de Janeiro 2: 35. 1935.

Prance et al. 11943, Brazil, Acre, Cruzeiro do Sul, Estrada Alemanha, flowering April 15 1971.

This species was previously known only by the many collections from the vicinity of Manaus. This new collection extends the known range considerably, see Fig. 1. The Acre collection has the same type of flaking bark which makes this species so easy to recognize in the field around Manaus.

Couepia glabra Prance, sp. nov.

(Fig. 3)

Arbor $10 \mathrm{~m}$ alta, ramulis juvenilibus mox glabris. Stipulae circa $2 \mathrm{~mm}$ longae, lanceola. tae membranaceae, caducae. Folia alternata petiolata, petiolo $8-12 \mathrm{~mm}$ longo, glabro, canali. culato, rugoso, eglanduloso, laminae oblongae vel oblongo-lanceolatae, $11-21 \mathrm{~cm}$ longae, 4-7 cm latae, coriaceae, apice in acuminem $5-9 \mathrm{~mm}$ longum, plerumque curvatae contractae, basi subcuneatae, utrinque glabrae; costa media utrinque prominenti; costis secundariis 16-17 jugis, subtus prominentibus, supra prominulis vel planis. Flores in paniculis terminalibus axillaribusque $4.5-9 \mathrm{~cm}$ longi dispositi vel raro in racemis dispositi, rachi ramisque minute sparse puberulis. Receptaculum cylindricoturbinatum $15-20 \mathrm{~mm}$ longum, extus in alabastrum minute sparse puberulum mox glabrum, intus prope faucem infra staminem pilis deflexis dense tomentosum, versus basim glabrum. Calycis-lobi 5, juvenili sparse puberuli mox glabri, marginibus ciliatis. Petala 5 glabra, cadaca. Stamina circa 110 , in orbem completum disposita, versus basim tomentosum, glabra. Ovarium ad faucem receptaculi insertum, pilosum. Stylus e basi ovarii ortus, versus basim sparse pilosus supra glabrus. Fructus mihi ignoti.

Type : Prance, D. Coêlho \& Monteiro 14942. Brazil. Amazonas, Rio Cueiras just below mouth of Rio Branquinho, flowering September 1971 (holotype, NY; isotypes, FHO, INPA).

Habitat: Forest on non-flooded ground.

Coupeia glabra is quite unlike any of the species already described, but it is probab!y closest to $C$. williamsii from which it differs in the usually paniculate inflorescence, the larger leaves, the almost glabrous style, the glabrous underside of the leaves, as well as in a number of additional small characters.

The material available contains 4 inflorescences, and I was able to observe these closely in the field since the terminal ones are reather different from the axillary ones. The inflorescence branches are very short in both inflorescences and often bear only a single flower in the axillary inflorescences the branches are sometimes much reduced giving a recemose appearance.

The leaves are also polymorphic since the apical ones are smaller and more oblong than the larger oblong-lanceolate leaves of the lower branches. Since I collected this species $\mathrm{m}$; self I was able to verify carefully this variation in the inflorescence and leaves, which is greater than in most species of Couepia.

Couepia krukovii Standl., Publ. Field Mus. Bot. $17: 250.1937$.

Prance et al. 16315, Brazil, Amazonas, Rio Purus between Redenção and Itaboca.

This is the first collection since the Krukoff types. It extends the known range of this species from the basin of the Rio Madeira to that of the Rio Purus.

Couepia longipendula Pilger, Notizbl. Bot. Gart. Berlin 6: 141. 1914.

Prance et al. 16143, Brazil, Amaoznas, Rio Curicuriari, foothills of Serra Curicuriari. flowering November 5, 1971: Prance et al. 16521, Brazil, Amazonas, Rio Cunhuá at Deni indian village, $6^{\circ} 43 \mathrm{~S}, 66^{\circ} 47 \mathrm{~W}$, fruiting November 29 1971.

This species was previously known only be the numerous collections form the vicinity of 


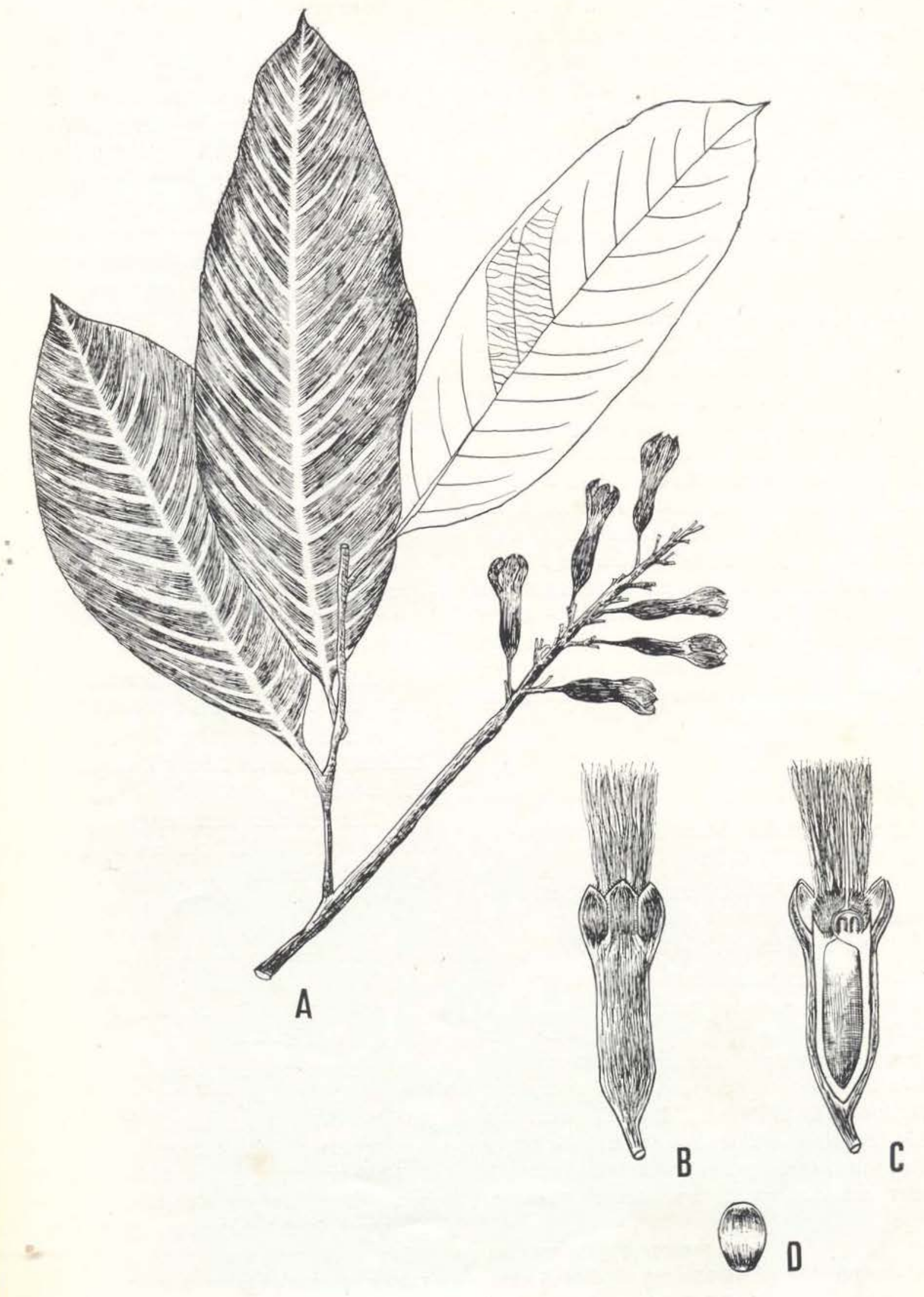

FIG. 3 - Couepia glabra (Prance et al. 14942). A, habit, x $0.5 ; \quad$ B, flower, $\mathrm{x} 1$; C, flower section, $\mathrm{x} 1$. 
Manaus. It is interesting that in fact it is obviously distributed in western Amazonia, as the collections cited above are from 2 widely separated localities well outside the previous known range of this species, see Fig. 1.

Couepia maguirei Prance, FI. Neotropica 9: 214. 1972.

\section{(Fig. 4)}

Prance et al. 16035, Brazil, Amazonas, Rio Negro at Camanaus, flowering November 2, 1971.

This species was described from material collected in Venezuela and higher up the Rio Negro in Brazil. The collection cited extends the known range slightly to the east down the Rio Negro, but it is mentioned mainly because I was able to observe the habitat and habit of $C$. maguirei better. This species is confined to rocky river islands, and is underwater for much of the year. As well as the few inflorescences in the upper branches, the majority of flowers are borne on separate flower-branches coming from the main trunk between $20-100 \mathrm{~cm}$ above ground level. Hence, this species can only flower during the dry season at low water, and the rising water washes off and distributes the fruits.

\section{Hirtella L.}

Hirtella excelsa Standl. ex Prance, FI. Neotropica 9: 345. 1972.

Maas et al. P/3134, Brazil, Acre, Rio JuruáMirim, Aldeota between Porangaba and Papagaio, flowering May 18, 1971.

This collection matches well other collections of $H$. excelsa except that it has a slightly branched inflorescence, and is therefore, not strictly racemose. The material with a branched inflorescence would key out to $H$. tocantina in Prance (1972). H. tocantina and $H$. excelsa are certainly more closely related than previously indicated. These 2 species are distinct in the characters listed below:

$\begin{array}{ccl} & \text { H. tocantina } & H \text {. excelsa } \\ \text { Leaf length } & 10-15 \mathrm{~cm} & 6-11.5 \mathrm{~cm} \\ \text { width } & 3.5 .5 \mathrm{~cm} & 2.3-4 \mathrm{~cm} \\ \text { Petiole length } & 3-5 \mathrm{~mm} & 1.5-2.5 \mathrm{~mm}\end{array}$

Inflorescente Always branched Racemose, or rarely slightly branched

This demonstrates that the character of racemose versus paniculate inflorescence is not as reliable for the division of Hirtella as indicated in some previous treatments of the genus. This was found in the preparation of Prance (1972), where several species were shown to have either racemose or paniculate inflorescences, e.g. $H$. hebeciada Moric. ex DC., $H$. paniculata $\mathrm{Sw}$ and $H$. rodriguesii Prance.

Hirtela rodriguesii Prance, FI. Neotropica 9: 310. 1972.

Prance et al 16141, Brazil, Amazonas, Rio Curicuriari, foothills of Serra Curicuriari, flowering November 5, 1971.

This species was previously collected in the vicinity of Manaus, and on the Rio Juruá. The new collection represents the first from the upper Rio Negro region of this recently described species.

Hirtella subscandens Spruce ex Hook if, Mart. FI. Bras. 14 (2) : 32. 1867

Prance et al. 15604, Brazil, Amazonas, Rio Uneiuxi, Campo de Dondona, flowering October 26, 1971.

This species was previously known only from Amazonian Venezuela, where it has been collected in similar habitats to the Dondona Savanna.

\section{Acioa Aubl.}

Acioa edulis Prance, sp. nov. (Fig. 5,6)

Arbor $25 \mathrm{~m}$ alta, trunco cum anteridibus usque ad $0.5 \mathrm{~m}$ alto, ramulis juvenilibus glabris. Stipulae 5-7 mm longae, membranaceae, glabrae, caducae. Folia alternata petiolata, petiolo $1.5-2.5 \mathrm{~cm}$ longo, glabro, tereti, laminae oblongae, $7-17 \mathrm{~cm}$ longae, $4.7-12 \mathrm{~cm}$ latae, crasse coriaceae, basi rotundatae, apice in acuminem $2.6 \mathrm{~mm}$ longum contractae, utrinque glabrae, subtus versus basim cum glandulis duobus munitae; costa media supra prominula subtus prominenti; costis secundariis 9-11 jugis, utrln- 

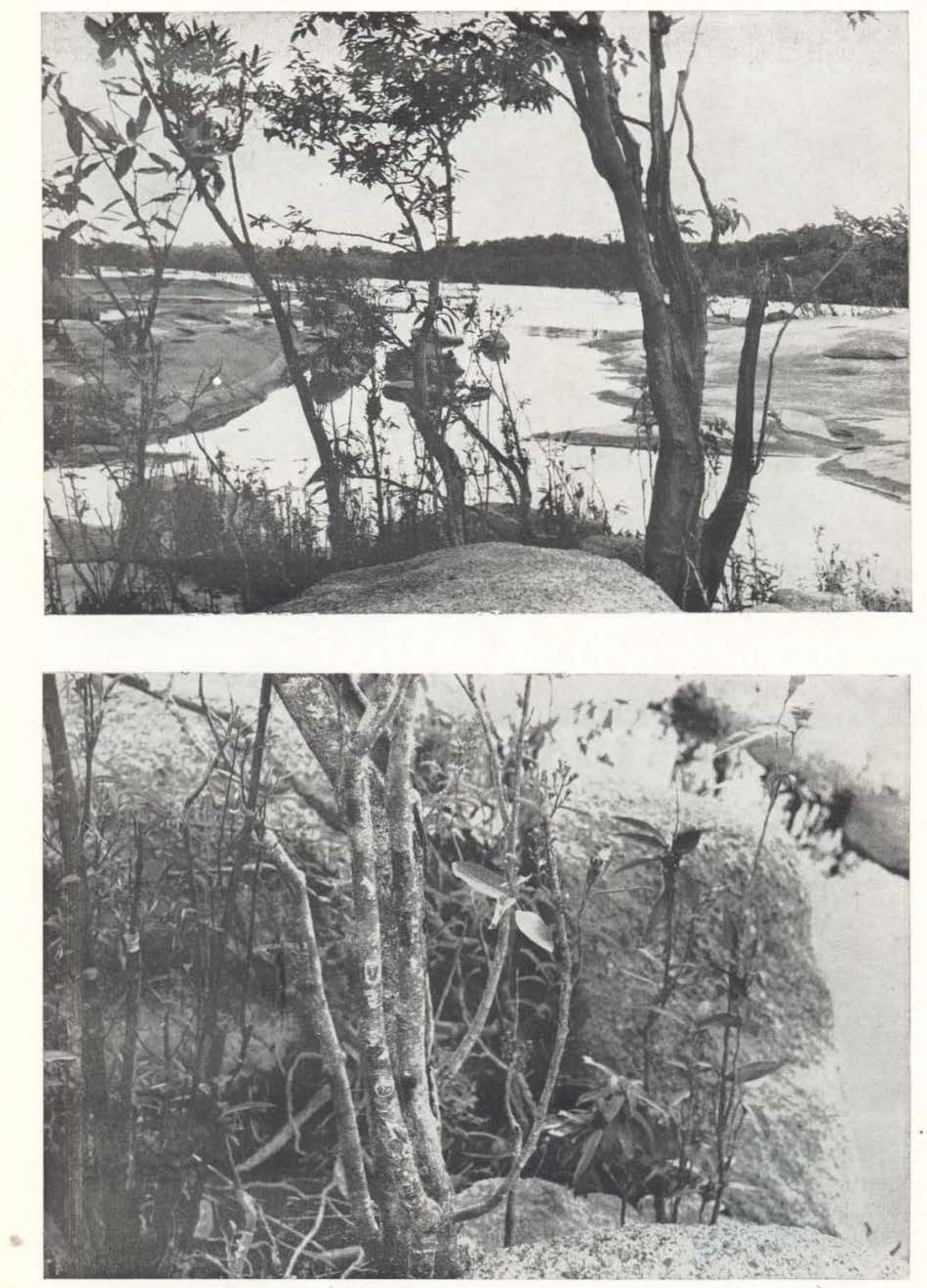

FIG. 4 - Photos of Couepia maguirei (Prance et al. 16035) showing habit and habitat, on Rio Negro at Camanaus. 


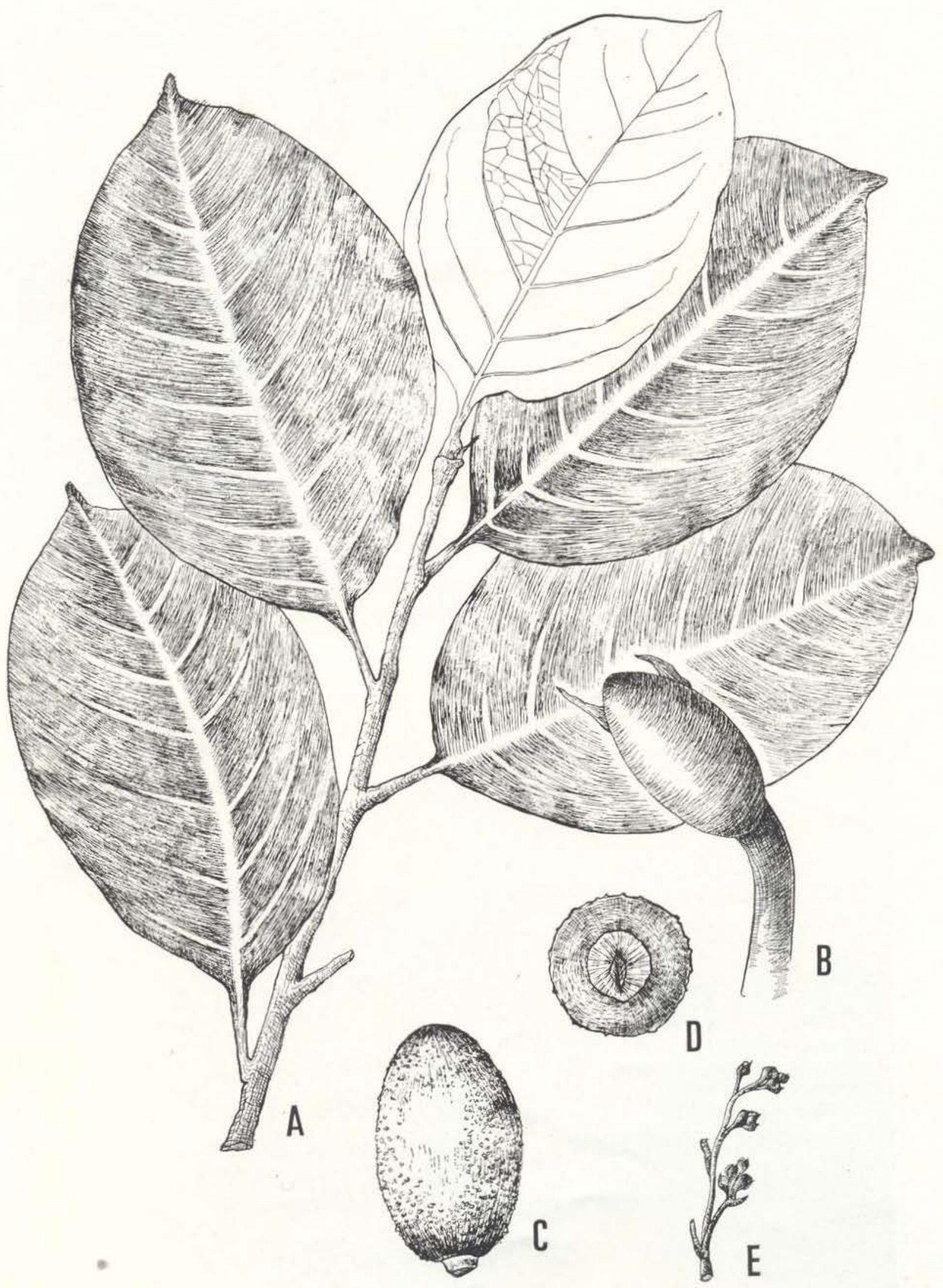

FIG. 5 - Acioa edulis (Prance et al. 14015, Krukoff 5822A). A, habit, x 0.5; B, germinating seedling showing cotyledons, $\mathrm{x} 0.5 ; \mathrm{C}$, fruit, $\mathrm{x} 0.5 ; \mathrm{D}$, transverse section of fruit, $\mathrm{x} 0.5 ; \mathrm{E}$, young inflorecence, $\mathrm{x} 0.5$. 

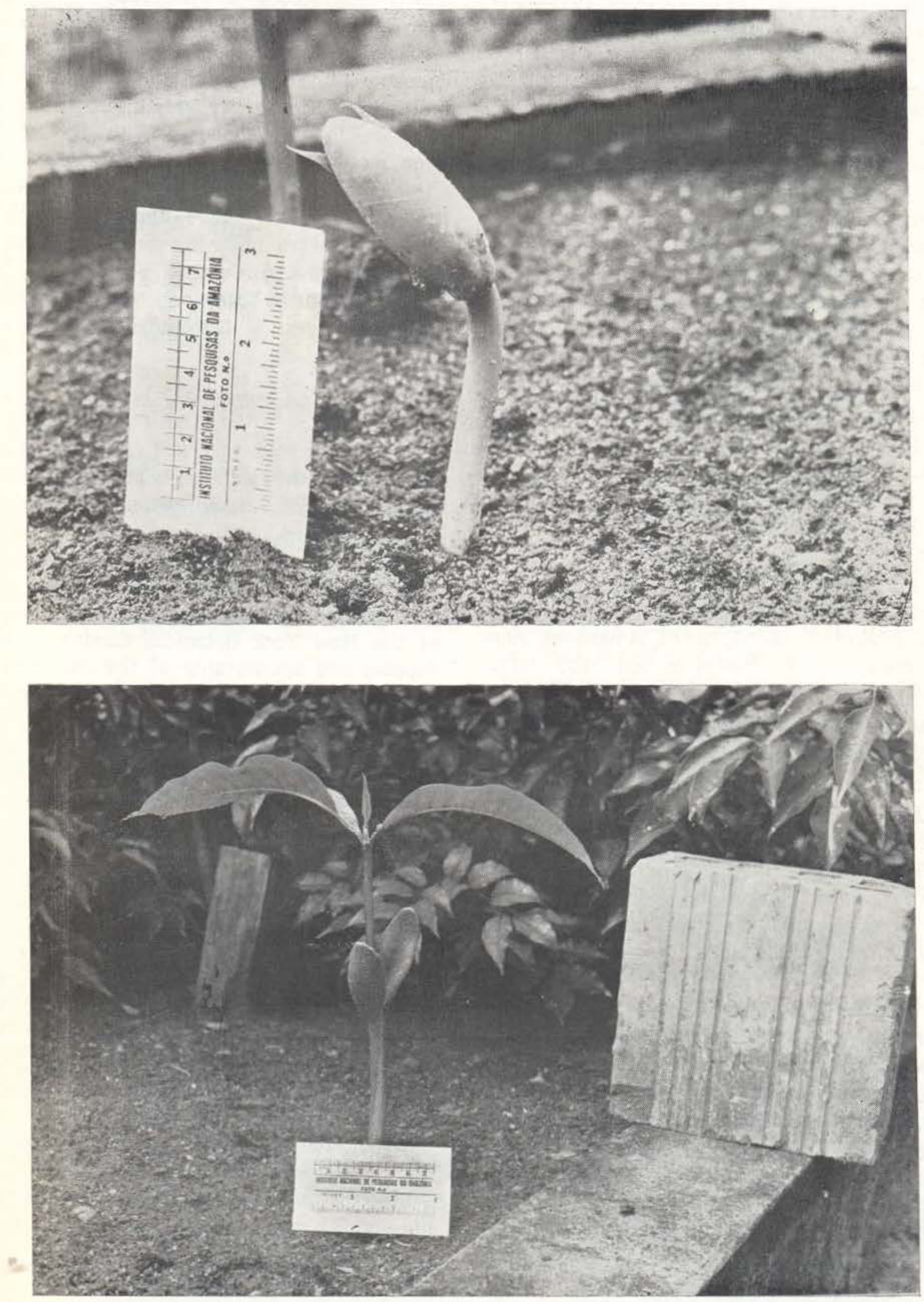

FIG. 6 - The seedling of Acioa edulis (Prance et al. 14015) 
que prominentibus; venis utrinque prominentibus. Flores (juveniles tantum visi) in paniculis terminalibus subterminalibusque paucifloribus dispositi, rachi ramisgue glabrescentibus. Bracteae bracteolaeque ovatae, membranaceae, extus glabrescentae. Receptaculum campanulato-turbinatum (in alabastrum) intus glabrum cum cavo-pauco munitum. Calycis lobi 5, rotundati, glabri, extus cum glandulis duobus muniti, intus griseo-pubescenti. Petala 5, glabra. Stamina circa $2^{\circ}$. Drupa ellipsoidea, 6-7.5 crn longa, $4.5 \mathrm{~cm}$ lata, epicarpio glabro lenticellato; epicarpio tenue, 12-14 $\mathrm{mm}$ crasso; endocarpio tenue osseo fragilo, intus glabro embryone loculo complenti, eduli. Germinatio epigaea; foliis primis oppositis.

Type: Prance, Maas, Atchley et al. 14015, Brazil, Amazonas, Rio Ituxi, Boca do Curuquetê. fruiting July 9, 1971 (holotype, NY; isotypes, FHO, INPA, MG, US).

Additional material examined: W. Rodri gues \& L. Coêlho 1408, Brazil, Amazonas, Lago de Tefé, fruiting November 20, 1959 (INPA, unicate); Krukoft 5822A, Brazil, Amazonas, Rio Ituxi, Boca do Remanzinho, in bud, 1933 (NY).

Habitat: Forest on non-flooded ground (terra firme). It was a common tree in the forest around Boca de Curuquetê the type locality.

Local name: Castanha de cotia.

Uses: The fleshy cotyledons are edible and the fruits are gathered in large numbers by Brazilians in the Rio Ituxi region. The kernel is eaten raw or is crushed and added to their tapioca cakes (Beijú). It is also used to extract the oil which is used cooking and for making soap.

In Prance (1972), I indicated that the collection Rodrigues \& Coêlho 1408, was possibly a new species, but I did not describe it from a single unicate collection with only half a fruit. During 1971 I was able to collect this species in another locality and to study it in the field as well as germinate the seedlings. The older collection, Krukoff 5882A, was studied for my monograph, and since it has only very young insect damaged flower buds it was set aside as a possible new species. With the additional new material it is now possible to describe it. This species is placed in the little collected genus Acioa with some hesitation since the mature flowers have not been examined and it could belong to Couepia. However, there is no doubt that it represents a hitherto undescribed species of Chrysobalanaceae.

\section{ACKNOWLEDGMENTS}

The 1971 field work was carried out through support of the National Science Foundation grant GB-18655. I am extremely grateful to the Director and staff of the Instituto Nacional de Pesquisas da Amazônia, Manaus, Brazil, for their assistance and joint sponsorship of the field program, and to the President and Directors of the New York Botanical Garden for their support and sponsorship of the fiel program. Finally I should like to thank Miss Claire Saraceni for preparing the line drawings.

\section{LITERATURE CITED}

Prance, G. T.

1972 - Chrysobalanaceae. Flora Neotropica, 9, 410 p.

\section{SUMMáRIO}

As mais recentes e importantes coleções feitas pelo autor na Amazônia brasileira como, tambem, al gumas realizadas por outros coletores, são comenta. das neste primeiro suplemento de sua monografia sobre Chrysobalanaceae Neotropicais. Licania jimenezii Prance, Couepia glabra Prance e Acioa edulis são aqui descritas como novas espécies. 